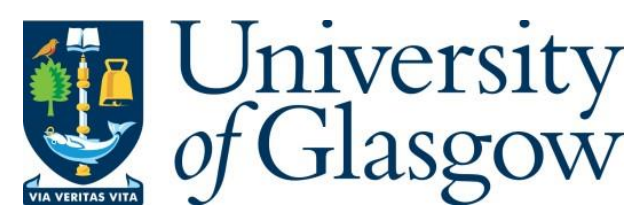

Yang, W. and Meyer, K. E. (2019) Alliance proactiveness and firm performance in an emerging economy. Industrial Marketing Management, 82, pp. 226-237.

There may be differences between this version and the published version. You are advised to consult the publisher's version if you wish to cite from it.

http://eprints.gla.ac.uk/177360/

Deposited on: 23 January 2020

Enlighten - Research publications by members of the University of Glasgow http://eprints.gla.ac.uk 


\title{
Alliance Proactiveness and Firm Performance in an Emerging \\ Economy
}

\author{
Wei Yang \\ Lecturer in Strategy \\ Adam Smith Business School, University of Glasgow \\ University Avenue, Glasgow, G12 8QQ, UK \\ Tel: +44 141-330-5668 \\ Fax: +44 141-330-5669 \\ E-mail: wei.yang@glasgow.ac.uk \\ Klaus E. Meyer \\ Professor of International Business \\ Ivey Business School, Western University \\ 1255 Western Road, London, Ontario, N6G 0N1, Canada \\ Tel: +1 512-661-2111 (Ext. 84292) \\ E-mail:kmeyer@ivey.ca
}

We thank colleagues at China Europe International Business School (CEIBS) and 2018 Academy of Management Conference reviewers for helpful comments. All remaining errors are our responsibility. Financial support from the National Natural Science Foundation of P. R. China [grant numbers 71732004 and 71532005] is gratefully acknowledged. 


\title{
Alliance Proactiveness and Firm Performance in an Emerging Economy
}

\begin{abstract}
Alliance proactiveness is a key contributor to the performance of firms engaging in strategic alliances in industrial markets. As a foundation of alliance management capability, alliance proactiveness enables firms to react faster to emergent opportunities and gain early mover advantages. We examine the relevance of this construct and its internal and external contingencies. Specifically, we argue that the impact of alliance proactiveness is enhanced by complementary technological and leadership capabilities, as well as market growth opportunities. We test hypotheses derived from these arguments using dual response survey data of firms in China and find empirical support.
\end{abstract}

Key words: alliance management capability, alliance proactiveness, leader strategic competences, technological capabilities, performance 


\section{INTRODUCTION}

Firms' ability to benefit from strategic alliances depends on their specialized resources in managing alliances (Dyer \& Singh, 1998; Schilke \& Goerzen, 2010). Thus, alliance management capability has been identified as pivotal to, for example, purposefully choose or be chosen as an alliance partner, to structure alliance relationships, and to learn from such alliances (Anand \& Khanna, 2000; Kale \& Singh, 2007; Sluyts, Matthyssens, Martens, \& Streukens, 2011). Alliance management capability is reflected in a set of routines by which organizations can change their resource base while engaging in strategic alliances (Schilke \& Goerzen, 2010) and represents a distinct type of dynamic capability that enables firms to "integrate, build, and reconfigure internal and external competencies to address rapidly changing environments" (Teece, Pisano, \& Shuen, 1997, p. 516). Thus, earlier studies have highlighted it as a key antecedent of alliance performance (Heimeriks \& Duysters, 2007; Kale \& Singh, 2007; Park, Chen, \& Gallagher, 2002).

Alliance proactiveness is a dimension of alliance management capability (Leischnig \& Geigenmüller, 2018; Sarkar, Echambadi, \& Harrison, 2001; Schilke \& Goerzen, 2010). Defined as "the extent to which an organization engages in identifying and responding to partnering opportunities" (Sarkar et al., 2001, p. 701), alliance proactiveness enables firms to identify and exploit opportunities to create value through synergies with potential alliance partners. Recent studies show that speed in identifying and exploiting partner resources increases competitive advantages that firms create in alliances (Ozdemir, Kandemir, \& Eng, 2017; Rothaermel \& Boeker, 2008; Sarkar, Aulakh, \& Madhok, 2009). However, we lack understanding of the contingencies under which alliance proactiveness, a key facet of alliance management capability, enhances firm performance. In addressing this gap in the literature, we posit that it helps firms to respond more effectively to new opportunities, and thereby outperform their competitors.

Our arguments are grounded in the resource-based perspectives of the firm, specifically the research streams on dynamic capabilities (Eisenhardt \& Martin, 2000; 
Teece et al., 1997) and relational capabilities (Dyer \& Kale, 2007; Mitrega, Henneberg, \& Forkmann, 2018; Pagano, 2009). Alliance management capability is a specific form of relational capability that has properties of dynamic capability in that it enables transformation of firm resources to pursue future business opportunities (Schilke \& Goerzen, 2010; Teece et al., 1997). However, we argue that alliance management capability alone is not sufficient. Firms also need resources that they can exploit in an alliance, or that they can offer to partners in exchange for other resources. Therefore, alliance proactiveness adds value to firms if they also can exploit complementary competences, notably - technological capabilities and leader strategic competences.

We contribute to scholarly knowledge in several respects. First, we explore the pivotal construct alliance proactiveness, which to date has received limited attention in the literature (Leischnig \& Geigenmüller, 2018; Sarkar et al., 2001). Specifically, by focusing on alliance proactiveness, we explore a critical capability that helps firms to gain access to complementary resources and shape the environment in their favor. In particular, alliance proactiveness is likely critical at early stages of alliance formation and in immediate market performance. Our focus thus enables finer-grained theoretical development and testing.

Second, we advance the alliance literature by exploring internal contingencies of alliance proactiveness. Prior studies analyze the direct effect of network and alliance management capabilities on firm performance (Medlin \& Ellegaard, 2015; Mitrega et al., 2012) as well as external contingencies such as competitive intensity and technological dynamism (Leischnig, Geigenmüller, \& Lohmann, 2014; Sarkar et al., 2001). We address the research gap regarding the interaction of firms' internal resources with alliance management capability (Park et al., 2002; Wang \& Rajagopalan, 2014). Specifically, we argue that complementary capabilities, i.e., technological capabilities and leader strategic competences, strengthen the association of alliance proactiveness with firm performance.

Third, recent reviews call for better explanations of how external contingencies of 
an emerging economy impact industrial marketing and strategy (e.g., Cui, Fan, Guo, \& Fan, 2018; Rungsithong, Meyer, \& Roath, 2017; Sheth, 2011; Wiersema, 2013), and alliance management in particular (Wang \& Rajagopalan, 2014). We respond by focusing on market growth because it opens new business opportunities that firms with resource constraints may not be able to pursue on their own. In such contexts, alliance proactiveness is likely particularly relevant. We investigate this contingency not only by introducing market growth as a moderating variable, but also by studying a volatile economy with many fast growing market segments, namely China, which provides an ideal context to disentangle the complexities of alliance management (Hitt et al., 2004; Park et al., 2002).

\section{CONCEPTUAL FRAMEWORK}

\section{Alliance management capability}

Alliances enable firms to access complementary resources and know-how that are controlled by their partner and unattainable in the market (Doz \& Hamel, 1998). In managing alliances, firms' abilities to assess the value of partner resources, assimilate them through alliances, and utilize them for commercial purposes are critical to enhance their competitive positioning (Dyer and Singh, 1998; Sluyts et al., 2011). As such, alliance management capability helps firms to develop new partnerships, and augment their resource base (Dyer \& Kale, 2007). It constitutes a specific form of dynamic capability that helps firms to transform their operational resources to sustain competitive advantages in changing environments (Schreiner, Kale, \& Corsten, 2009).

The importance of alliance management capability and related constructs has been emphasized in particular by the relational view of strategy, which focuses on capabilities in managing relationships as driver of competitive advantage (Dyer \& Singh, 1998; Mitrega et al., 2012; Morgan, Vorhies, \& Mason, 2009; Murphy \& Li, 2015; Pagano, 2009). For example, Kale and Singh (2007) interpret alliance management capability as a process through which firms learn, accumulate, and leverage alliance know-how. Similarly, Heimeriks and Duysters (2007, p. 30) suggest 
that learning from alliances increases "a firm's ability to perform repeatable patterns of action with respect to, for instance, identifying partners, initiating relationships, or restructuring alliances". It enables firms not only to benefit from singular alliances, but from a portfolio of alliances (Sarkar et al., 2009). Empirical studies confirm the importance of alliance management capability, showing its association with performance indicators at multiple levels of analysis, including new product development (Rothaermel, 2001), operational performance (Rungsithong et al., 2017), alliance portfolios (Heimeriks \& Duysters, 2007) and stock market value (Anand \& Khanna, 2000).

Schilke and Goerzen (2010) and Leischnig and collaborators (2014) deconstruct the concept of alliance management capability into four sets of routines - alliance coordination, inter-organizational learning, alliance transformation and alliance proactiveness: (a) Alliance coordination comprises the governance of specific alliances and the integration of all of a firm's alliances. (b) Inter-organizational learning concerns firms' capability to effectively gain knowledge from alliance partners. (c) Alliance transformation concerns firms' routines to modify alliances to establish fit between partners. (d) Alliance proactiveness refers to the capability to sense alliance opportunities early and evaluate partners for gaining resources.

Sarkar and collaborators (2009) argue that the dimensions of alliance management capability may be independent, rather than covarying. For instance, some firms may be highly capable in initiating alliance but less competent at managing (mature) alliances in a portfolio of partners. Firms that proactively form alliances are better able to create unique resource constellations, which in turn help to develop skills and knowledge within an alliance (Sarkar et al., 2001). In particular, early entry gives proactive firms a head start to cumulative alliance learning, which is likely to create more value for the firm (Anand \& Khanna, 2000). Thus, of the four types of routines, we turn to alliance proactiveness as focal construct of our study. 


\section{Alliance proactiveness}

The construct of 'proactiveness' originates in the entrepreneurship literature, where it is considered as one of three dimensions of entrepreneurial orientation (EO) along with risk taking and innovativeness (Covin \& Slevin, 1989). Entrepreneurship scholars define proactiveness as "how a firm relates to market opportunities in the process of new entry. It does so by seizing initiative and acting opportunistically in order to 'shape the environment', that is, to influence trends and, perhaps, even create demand" (Lumpkin \& Dess, 1996, p. 147). Proactive entrepreneurs continuously seek new opportunities and experiment with novel responses to environmental change (Venkatraman, 1989). Empirical studies have shown that such proactiveness enhances the performance of entrepreneurial firms not only as a component of the broader concept of EO, but on its own (Hughes \& Morgan, 2007; Kreiser et al., 2013; Miller 2011). Recently, similar findings have been reported for China, indicating the relevance of the concept for emerging economies (Cui et al., 2018; Sheth, 2011).

Strategy scholars have adopted the concept of proactiveness to identify the success factors in strategic alliances (Sarkar et al., 2001). In particular, partners in an alliance may create value not only by accessing and integrating strategic resources and know-how from each other, but by doing so proactively. Encompassing opportunity sensing and response capability, alliance proactiveness thus consists of "organizational routines that enable a firm to identify and preempt new and valuable partnering opportunities" (Sarkar et al., 2009, p. 587).

Alliance proactiveness allows firms to utilize complementary resources to preempt competitors (Rothaermel \& Boeker, 2008). Firms can choose to either enter an alliance ahead of competitors or wait until a later stage when alliance outcomes can be better predicted (Ozdemir et al., 2017). Early movers in alliances can shape the environment in their favor (Frynas, Mellahi, \& Pigman, 2006), and secure scare resources ahead of competition (Lieberman \& Montgomery, 1998; Medlin \& Ellegaard, 2015; Sarkar et al., 2001). In the pool of potential alliance partners, there likely is competition for the most attractive partners. If a firm is too slow to contract 
the 'best' partner, it may be left with less favorable options, which reduce partnership gains (Gulati, 1995). Thus, early movers may impede rivals from obtaining ties by forming exclusive alliances with key players in an industry (Ozcan \& Eisenhardt, 2009). In contrast, it can harm a firm if the best potential partners ally with a major rival, further intensifying the competition.

Alliance proactiveness helps firms to develop relationships with old and new partners (Kale, Dyer, \& Singh, 2002). Alliances are rarely stand-alone activities; many successful firms manage portfolios of alliances with many, diverse partners. These alliance portfolios potentially provide more information, flexibility and resources and thereby enhance firms' absorptive capacity (Andrevski, Brass, \& Ferrier, 2016; Baum, Calabrese, \& Silverman, 2000).

\section{Complementary resources}

Alliance proactiveness is most valuable when combined with other types of capabilities, notably to integrate marketing and technological aspects of an operation (Song, Droge, Hanvanich, \& Calantone, 2005; Wilden \& Gudergan, 2015). We investigate two types of complementary resources, technological capabilities and leader strategic competences. Both types of resources enhance firms' attractiveness as an alliance partner, and hence alliance success (Kale, et al., 2002; Leiblein \& Miller, 2003). Based on Afuah (2000), we define technological capabilities as firms' ability to employ technological resources such as patents, technical experts, and technical knowledge. They are one of the most sought-after types of resources in alliances (Hagedoorn \& Schakenraad, 1994; Hitt, et al., 2004), and enable the development of products, foster innovation, reduce costs, and achieve higher growth rates (e.g., Calantone, Cavusgil, \& Zhao, 2002; Powell, Koput, \& Smith-Doerr, 1996; Stuart, 2000).

Strong technological capabilities make a firm an attractive alliance partner (Lin, Yang, \& Arya, 2009). They enable firms not only to identify opportunities for technological advancement (Lane \& Lubatkin, 1998), and to identify alliance partners 
with the most valuable complementary technological knowledge, but to effectively accumulate new relevant knowledge in alliances (Leiblein \& Miller, 2003; Leischnig et al., 2014), and to facilitate subsequent assimilation of new knowledge (Gulati, Lavie, \& Singh, 2009; Lee, Lee, \& Pennings, 2001).

Top management capabilities influence firm strategy and its effectiveness (Finkelstein \& Hambrick, 1996). We focus on leader strategic competences, defined as leaders' ability to evaluate market trends and to timely develop strategies to capture market opportunities (He \& Li, 2005; Yang \& Meyer, 2015). This construct incorporates top management capabilities in managing resources effectively (Lado, Boyd, \& Hanlon, 1997) with the risk-taking and innovative tendency in strategic decision-making (Miller, 2011; Sharma \& Vredenburg, 1998). Successful businesses rely on leaders' capabilities to identify and select opportunities to create and deliver value (Ardichvili, Cardozo, \& Ray, 2003), to sense market needs and to spot suboptimal resource deployment (Alvarez \& Busenitz, 2001). These leader strategic competences enable firms to make the best use of alliances to capture new opportunities (Santos \& Eisenhardt, 2009). For example, Kale et al. (2002) suggest that visionary leaders and strong management with focused dedication may be necessary to ensure short- and long-term alliance success.

In terms of external conditions, market growth in particular provides growth opportunities for firms that have appropriate resources to capture new opportunities (Li \& Miller, 2006; Park et al., 2002). Thus, growth opportunities may encourage firms to expand their alliance network to leverage partner resources, and to overcome internal resource and capability constraints (Ozdemir et al., 2017). Where customer demand changes rapidly, proactive alliance formation can facilitate the development of new product and service offerings to quickly enter new markets (Leischnig \& Geigenmüller, 2018; Sarkar et al., 2001).

In summary, alliance proactiveness is widely believed to enhance alliance performance, but we suggest that this effect is dependent on firm internal and external contingencies. Firm capabilities and the market environment moderate the outcomes 
of alliance decisions (Lavie, 2006; Sarkar et al., 2001). Hence, to develop our hypotheses, we first examine the impact of alliance proactiveness on firm performance, and then examine how this relationship is moderated by capability- and environment-related factors. Figure 1 summarizes our theoretical framework.

\section{*** Insert Figure 1 about here ***}

\section{HYPOTHESES}

\section{Alliance Proactiveness and Performance}

Proactive formation of alliances enables firms to gain a competitive advantage for three main reasons. First, only a small number of 'best' (e.g., more prominent, resource-rich, experienced) alliance partners may be available, which leaves late movers with suboptimal options (Rothaermel, 2001). Thus, alliance proactiveness can help firms to realize first-mover advantages, especially when future relationships tend to evolve from earlier relationships (Baum et al., 2000; Gulati, 1995). For instance, Powell et al. (1996) find that biotech ventures achieved superior growth by quickly obtaining many R\&D alliances, while Sarkar et al. (2009) find better performance for proactive firms with strong partner-search capability.

Second, early movers may create entry barriers by forming alliances that inhibit entry by third parties and thereby create a source of competitive advantage (GomesCasseres, 1996; Lavie, 2006). For instance, Santos and Eisenhardt (2009) find that successful entrepreneurs build networks with established firms to deter competitors from entering a market. Third, early movers in alliances can signal the quality of their own activities and products to external parties such as suppliers (Powell, 1998). A portfolio of high-quality alliances is thus likely to help firms to build 'alliance portfolio capital' that reflects their ability to create value from alliances (Andrevski et al., 2016; Sarkar et al., 2009).

To make alliances successful, firms need to engage actively and continually in relationship building and learning processes (Rothaermel \& Deeds, 2004). Firms that engage in alliances proactively start their learning processes earlier and more 
systematically. Early participation enables firms to start earlier in sliding down their technology learning curve (which depends on cumulative output), and hence to enhance their competitive advantage (Kale \& Singh, 2007; Sarkar et al., 2001). Moreover, proactive firms accumulate knowledge on processes of identifying and selecting partners (Reuer, Zollo, \& Singh, 2002). By staying ahead in learning processes, proactive firms may be able to pre-empt competition (Kale et al., 2002; Rothaermel \& Deeds, 2004). For example, Ozdemir, Kandemir, and Eng (2017) find that proactive new product alliances enable firms to improve performance both in new product development and overall.

In summary, alliance proactiveness creates a competitive advantage for firms over those that are either unable, or unwilling, to act proactively (Anand \& Khanna, 2000; Sarkar et al., 2001). Thus, we propose that alliance proactiveness is positively associated with the performance of a firm.

\section{H1: Alliance proactiveness is positively associated with firm performance.}

\section{Capabilities as Moderators}

\section{Technological capabilities}

The extent to which alliance proactiveness enhances firm performance depends on complementary capabilities of the firm. Many alliances aim to pool technological resources with the aim to more swiftly identify, develop and market new products and services (Hagedoorn \& Schakenraad, 1994; Powell et al., 1996). Firms with stronger technological resources not only have more to contribute to an alliance (thus making the alliance more successful), but also likely have stronger absorptive capacity to integrate knowledge generated in the alliance to their own organization (Rothaermel \& Deeds, 2004; Stuart, 2000). Thus, technologically capable firms are better able to manage inter-organizational technology transfers, and thereby can exploit existing and new knowledge in an alliance (Leischnig et al., 2014).

Moreover, technology makes firms more attractive to potential alliance partners, and puts them in an advantageous position to create successful alliances (Gulati, 
Lavie, \& Singh, 2009; Hagedoorn \& Schakenraad, 1994). Thus, technological resources help both the formation and management of alliances. For example, Haeussler, Patzelt, and Zahra (2012) find that technological capabilities moderate the impact of different types of alliances on new product development.

In volatile markets, alliance partners may have to access, acquire and assemble resources quickly, which can create frictions and alliance failure. In particular, firms that enter alliances prematurely under unfavorable conditions face the risk of expropriation of their knowledge (Jiang et al., 2013; Teece, 1986). Firms with strong technological capabilities can not only mitigate such alliance risks (Haeussler et al., 2012), but also rapidly identify and access partner technologies and exploit complementary resources to enhance their own market performance (Rothaermel, 2001; Rothaermel \& Boeker, 2008).

Thus, we propose that technological capabilities strengthen firms' ability to enhance performance by proactively engaging in alliances. A proactive firm can move faster than its competitors to deploy and exploit technologies within an alliance, suggesting a complementarity of alliance proactiveness and technological capabilities. Thus, we propose the following interaction driving firm performance:

\section{H2: A firm's technological capabilities enhance the positive association of alliance} proactiveness with firm performance.

\section{Leader strategic competences}

The mindset, vision and cognitive views of its leaders influence firms' alliancerelated strategic choices (Lado et al., 1997; Ozcan \& Eisenhardt, 2009). Firms with strong leader strategic competences are more sensitive to market trends, act more quickly on new opportunities, and mobilize resources more effectively (Finkelstein \& Hambrick, 1996; Holcomb, Holmes, \& Connelly, 2009; Montgomery, 2008). Strategic competences enable leaders to leverage their experience to make more effective alliance decisions. Leaders' abilities in entrepreneurial decision-making and in 
mobilizing internal resources to pursue alliance opportunities are thus important sources of firm heterogeneity (Alvarez \& Busenitz, 2001).

When it comes to developing alliances, strategic competences help leaders to make faster alliance moves and manage them to ensure alliance success (Kale, Dyer, \& Singh, 2002). For instance, Ozcan and Eisenhardt (2009) find that executives' cognitive views determine the strategic alternatives from which they choose: "executives in firms with high-performing portfolios visualize their portfolios in the context of an entire network, not as a series of single ties" (p. 268). After identifying alliance opportunities, leaders manage the alliances, which requires creative combination of (underutilized) resources such as technologies, inventions and ideas to create value (Rothaermel \& Boeker, 2008). Leadership competences thus play a critical role in implementing proactive formation of alliances.

We argue that leaders with superior market scanning and organizing capabilities can make proactive pursuit of alliances more successful. In other words, stronger leader strategic competences increase the positive performance effect of alliance proactiveness. Thus, we propose:

\section{H3: A firm's leader strategic competences enhance the positive association of alliance} proactiveness with firm performance.

\section{Environmental Moderation}

Environments that are dynamic, competitive and uncertain induce firms to engage in more aggressive competition (D’Aveni, Dagnino, \& Smith, 2010). Prior research suggests that in hypercompetitive environments, it is crucial for firms to create new paths, such as proactive alliances, to faster develop and commercialize new products, and hence to be early in exploiting new market opportunities (Katila, Rosenberger, \& Eisenhardt, 2008; Park et al., 2002). More generally, dynamic capabilities such as alliance management capability are more important in fast growing markets (Eisenhardt \& Martin, 2000). Applying this insight to alliances, Sarkar et al. (2001, p. 703) argue that "the extent to which alliance-related entrepreneurial motivation 
creates value depends on the 'richness' of environmental opportunities".

High market growth enhances market opportunities, and thereby provides incentives for firms to ally more rapidly with partners to realize new business opportunities. Markets with fast growth and many potential customers offer firms greater potential to succeed by quickly offering new products and services, and those firms that can effectively leverage partner resources are more likely to be first to market. Thus, for instance, Park, Chen, and Gallagher (2002) find that in high growth markets resource-rich firms are more likely to form alliances, which has a positive impact on firm performance. Similarly, Sarkar et al. (2009) find that market dynamism increases the financial returns of alliance proactiveness, while Leischnig and Geigenmüller (2018) find market dynamism to be a causal condition of performance in some strategy-environment configurations.

These arguments suggest that market growth is associated with greater volatility and more frequent emergence of new opportunities, which are conditions that make proactive formation of alliances particularly valuable. Thus, we propose a positive moderating effect of market growth on the relationship between alliance proactiveness and firm performance.

\section{H4: Market growth enhances the positive association of alliance proactiveness with firm performance.}

We have previously argued that firms that can combine alliance proactiveness and technological capabilities are better able to react to market opportunities through the formation of strategic alliances. The scale and scope of market opportunities is closely associated with market growth, especially in emerging economies. In a fast growing economy, thus, companies that can quickly exploit technologies by collaborating with suitable partners are more likely to gain competitive advantages. Therefore, we expect the interaction between alliance proactiveness and technological capabilities to be particularly potent in fast growing markets. This suggests a three-way interaction between alliance proactiveness and its internal and external contingencies as follows: 
H5: Market growth enhances the positive interaction between alliance proactiveness and technological capabilities in driving firm performance.

\section{METHODOLOGY}

\section{Research setting}

We have previously argued that alliance proactiveness is likely particularly relevant in markets that are volatile and/or fast growing. Therefore, we have chosen as our empirical field China, which has experienced high levels of market growth and volatility in recent years (Luo, 2003; Zhang \& Wu, 2017). In China, firms have to continuously adapt to changes by employing flexible strategies such as alliances. Alliance strategies (including joint ventures) in China have undergone several stages. During the 1980s and 1990s, equity alliances were the predominant form of foreign firms' operations in China, largely due to the regulatory constraints imposed by the Chinese authorities. Since China's entry into the World Trade Organization in 2001, regulations in many industries have been relaxed, facilitating wholly foreign owned enterprises. More recently, however, foreign firms choose equity alliances voluntarily in response to greater local competition, as well as to gain access to indigenous knowledge of local partners (KPMG, 2012). More broadly, we study alliances in general, including all forms of implicit and explicit cooperative agreements with external partners.

We have selected industries with competitive market structures and low levels of government regulation that might suppress competition and alliance activities. The industries are beauty and personal care, consumer appliances, computing equipment, food and beverages, machinery, medical devices, transport and telecommunications, and retail. In these industries, firms tend to use alliances for competitive objectives rather than to meet regulatory requirements.

\section{Sample and data collection}

Following the convention of research on alliance management capability (Heimeriks \& Duysters, 2007; Schilke \& Goerzen, 2010), we conducted a 
questionnaire survey to collect primary data. In China, however, response rates in mail surveys are typically low (Li \& Miller, 2006). Thus, we worked with China Europe International Business School (CEIBS), a leading business school in China, and contacted participants of their Executive MBA and Executive Education Programs, which recruit mostly senior executives. To pre-empt issues of common method variance (CMV), we asked two respondents from each participating firm to complete a part of the questionnaire: a top executive answered questions related to firm properties, capabilities and industry conditions, while a middle-level manager responded to questions on alliance activities of the main business unit, and business unit performance outcomes. ${ }^{1}$

The senior respondents were key decision-makers of their firms. The majority served as President/Chief Executive Officer (CEO), Vice President/Chief Finance Officer (CFO)/Chief Operation Officer (COO), board member, or chairperson. In several cases, the respondent was also the founder. The middle-level managers were responsible for sales, marketing and business development functions. We combined an online and an offline survey to ensure a reasonable response rate.

The survey instrument was first developed in English, and then translated into Chinese by two independent translators who discussed each inconsistence until they reached an agreement. Before sending out the survey instrument, we tested it in a pilot with 10 senior and middle-level managers. This pilot helped to confirm the face and construct validity of each item, and the feedback from the pilot helped to improve the wording of items in the survey instrument.

Each target person received a personalized cover letter in which we offered a complimentary summary of the results. Moreover, we allowed respondents not to disclose their name, and instructed them to respond to the questions based on an immediate impression after reading the questions rather than deep reflection. These instructions aimed to reduce CMV, following guidelines by Podsakoff and

\footnotetext{
${ }^{1}$ We also enquired on the top executive about the alliance performance measures. However, due to missing data, we did not use this measurement.
} 
collaborators (2003).

This study is part of a larger research project on dynamic competition of domestic and foreign firms in China. We contacted senior managers of 2,620 firms. For firms whose senior managers responded to our survey, we followed up with a separate survey to middle-level managers of their main business unit. We received matched responses from 140 firms, of which 9 had missing values. Thus, the 131 firms with complete, matched responses are the sample for our analysis. Of these 131 firms, 93 used alliances in the previous year, and 38 firms did not. Among the 93 firms that employed alliances, a majority of 51 firms (55\%) operated in business-to-business segments; 64 firms (69\%) had more than 500 employees; 65 firms (70\%) were Chinese-owned, and 28 firms (30\%) were foreign-owned.

\section{Dependent variable}

Respondents rated the performance of their main line of business relative to their major competitors in the past 12 months, using six items: market share growth, acquiring new customers, increasing sales to current customers, growth in sales revenue, business unit profitability, reaching financial goals (Morgan, Vorhies, \& Mason, 2009). Responses were recorded on a 7-point Likert scale ( $1=$ "much worse than competitors", 7 = "much better than competitors"). Performance was evaluated by the middle managers who were most familiar with the business unit. The composite reliability in this measure is 0.828 , see Appendix A.

\section{Independent variables}

\section{Alliance proactiveness}

We follow Ferrier, Smith, and Grimm (1999), and asked respondents (i.e., middle managers) to aggregate the alliance actions of a business unit of the focal firm in the current year. This approach enables conducting the analysis on a business-unit level, and ensures the key informants were well informed and qualified to respond to the survey questions (Schilke \& Goerzen, 2010). Respondents assessed the alliance speed and alliance frequency of their business unit in initiating alliances. As alliance 
management capability is a relative capability, we measured it vis-à-vis the major competitor. Alliance speed measures how rapidly the business unit of the focal firm has initiated an alliance or cooperative agreement compared with its major competitor within the last 12 months. Responses were obtained on a 7-point Likert scale ( 1 = "far slower than competitor", 7 = "far faster than competitor") for the alliance actions. Alliance frequency measures whether the business unit of the focal firm has initiated more or less alliances compared with its major competitor within the last 12 months. Responses were obtained from a 7-point Likert scale ( 1 = "far fewer than competitor", $7=$ "far more than competitor") for the alliance actions. We take the average of alliance speed and alliance frequency for the measure of alliance proactiveness. The composite reliability of this measure is 0.897 .

We employed previously validated items for the internal and external moderators. We measure technological capabilities by a five-item measure assessing technological capabilities vis-à-vis a firm's major competitors, which we adopted from Zhou and $\mathrm{Wu}$ (2010). Responses were obtained on a 7-point Likert scale $(1=$ "much worse than competitors", 7 = "much better than competitors"). The composite reliability of this variable is 0.884 . We measure leader strategic competences by the capabilities of senior managers to position the business, formulate strategy, and adjust to rapid environmental changes. We employed a six-item scale adopted from $\mathrm{He}$ and $\mathrm{Li}$ (2005), also using a 7-point Likert scale ( 1 = "much worse than competitors", $7=$ "much better than competitors"). This variable has a composite reliability of 0.906 . Both technological capabilities and leader strategic competences were evaluated by the senior managers as these are firm-level capabilities.

Market growth measures how fast the markets are growing in which the firm is operating. We used a three-item scale from Zhou and Wu (2010) on a 7-point Likert scale ( 1 = "strongly disagree", 7 = "strongly agree"). The composite reliability of this measure is 0.850 . Details of all variables are reported in Appendix A.

\section{Control variables}


We included several firm-level control variables suggested in the literature. Firm age is measured by subtracting the year of establishment or incorporation from the year of the survey, 2012. Firm size is measured by the natural logarithm of the firm's number of employees. Moreover, two dummies capture differences in ownership: Wholly foreign takes the value of 1 if the firm is wholly foreign owned, whereas joint venture takes the value of 1 if ownership is shared between two or more partners. ${ }^{2}$

Industry is controlled for by two dummy variables. The first takes the value of 1 for manufacturing, and 0 for services. The second industry dummy focuses on the type of target customers, with 1 for business-to-consumer (B-to-C), and 0 for business-to-business (B-to-B).

\section{Analytical approach}

As in most sampling procedures, a concern is the potential for sample selection bias. In particular, firms that are likely to perform better may choose to use alliances in the first place. Following Hamilton and Nickerson (2003), we use a two-stage estimation procedure based on Heckman (1979) to examine the effect of alliance proactiveness on firm performance, controlling for the first-stage decision to engage in alliances at all. The first-stage equation was estimated as an independent Probit model predicting whether or not a firm used alliances in the year 2011. In this Probit regression, the dependent variable is a dummy variable capturing the decision to employ alliances or not. Thus, this dummy variable takes the value of 1 if a firm had employed alliances, and 0 otherwise. Of the 131 firms that provided dual survey responses, 93 firms employed alliances and hence were coded 1, and 38 firms did not employ alliances and hence were coded 0 . The inverse-Mills ratio generated in the Probit regression was then included in the second-stage regression as an additional control variable to adjust for potential selection bias.

According to best practices, the first-stage Probit regression needs to include at

\footnotetext{
${ }^{2}$ Note that this study investigates strategic alliances of the focal firm. If that focal firm itself is a joint venture (and hence a strategic alliance between two or more firms), then this is captured by this control variable.
} 
least one variable that influences selection but not the subsequent outcome of interest to correct for potential endogeneity (Hamilton \& Nickerson, 2003). We choose as instrumental variable for this purpose Industry life cycle, which thus is included in the first-stage, but excluded in the second-stage model of firm performance.

\section{Psychometric properties of measurement scales}

In Table 1, we report the means, standard deviations, and correlations of the variables used in the second-stage regression. We calculated variance inflation factors (VIF) for all variables and found multi-collinearity not to be a severe problem. Since the dependent variable and some of our independent variables were derived from the same questionnaire instrument (i.e., middle-level management), CMV might affect our results. The following actions help us to minimize the chance of CMV affecting our results and to enhance our construct validity.

\section{*** Insert Table 1 about here ***}

First, our main hypotheses concern moderating effects, and the moderating variables were obtained from a different respondent (i.e., senior management) than the dependent and independent variables (i.e., middle-level management). This limits the possibility of these results being affected by CMV. Second, we conducted a number of additional tests to assess if CMV is a substantive concern. As suggested by Anderson and Gerbing (1988), we adopted a two-step approach to estimate measurement models. First, we used CFA to assess the psychometric properties of the multiple-item scales. We then estimated an overall, four-factor confirmatory measurement model. The model has a satisfactory fit with an overall model fit $\chi^{2} / \mathrm{df}=1.234$, comparative fit index $[\mathrm{CFI}]=0.982$, incremental fit index $[\mathrm{IFI}]=0.983$, root mean square error of approximation $[\mathrm{RMSEA}]=0.05)$. Moreover, we tested a one factor model with the alternate conceptualization of this construct (overall model fit $\chi^{2} / \mathrm{df}=7.329, \mathrm{CFI}=$ $0.454, \mathrm{IFI}=0.465, \mathrm{RMSEA}=0.262)$. These results indicate that the four-factor model provides a better fit. Moreover, all factor loadings exceed 0.657 (all t-values greater than 7.62), which provides evidence of convergent validity among our measures. 
Finally, we conducted two tests to assess the discriminant validity of our measures. First, we calculated the shared variance between all possible pairs of constructs, which we compared with the average variance extracted (AVE) of each construct. For each construct, we found that the AVE is much higher than the highest shared variance, which suggests discriminant validity among our constructs. Second, we used two-factor CFA models including each possible pair of constructs, with the correlation between the two constructs first fixed as 1 and then freely estimated. All $\chi^{2}$-values of the freely estimated model were significantly lower than the restricted model, which indicates discriminant validity (Anderson \& Gerbing, 1988). Thus, we are confident that our constructs have adequate measurement properties. ${ }^{3}$

\section{Results}

Table 2 reports the results of our two-stage Heckman regression analysis. Model 1 reports the results of the first-stage selection model (the decision to engage in alliances), and Models 2 to 9 show results of the second-stage firm performance model. For the purpose of testing our hypotheses, we focus on Models 2 to 9. In Hypothesis 1, we proposed that alliance proactiveness has a positive impact on performance. Model 2 shows that alliance proactiveness is statistically significantly associated with performance $(b=0.199, p=0.001)$, in line with for Hypothesis 1 .

\section{*** Insert Table 2 about here ***}

As technological capabilities and leader strategic competences are correlated at $\mathrm{r}=0.49$, we examine their moderating effects separately (Model 6 and Model 7). In Hypothesis 2, we proposed that technological capabilities positively moderate the alliance proactiveness-performance relationship. Model 4 shows that the interaction effect of alliance proactiveness and technological capabilities on performance is

\footnotetext{
${ }^{3}$ We acknowledge the possibility of endogeneity of technological capabilities or leader strategic competences with proactiveness, as resources drive strategies. We empirically tested the impact of technological capabilities/leader competence on proactiveness. We found that the impact of technological capabilities/leader competence on proactiveness is not statistically significant. Thus, we infer that endogeneity is not a severe issue in this study.
} 
statistically significant ( $b=0.384, p=0.000)$. In Model 6 , the moderating effect of technological capabilities remains statistically significant $(b=0.328, p=0.000)$ when the moderating effect of market growth is considered. When the three interactions are considered together, the moderating effect of technological capabilities remains significant $(b=0.268, p=0.028$; Model 8$)$, in line with Hypothesis 2 . The moderating effect is illustrated in Figure 2.

\section{*** Insert Figure 2 about here ***}

In Hypothesis 3, we proposed that leader strategic competences have a moderating effect on the relationship between alliance proactiveness and performance. Model 5 shows that the interaction of alliance proactiveness and leader strategic competences on performance is statistically significant $(b=0.344, p=$ 0.000). In Model 7, the moderating effect of leader strategic competences remains statistically significant $(b=0.273, p=0.005)$ when the effect of market growth is added. However, when the three interactions are all considered, the moderating effect of leader strategic competences is not significant any more $(b=0.097, p=0.438$; Model 8). Thus, the impact of strategic leader competence is dominated by technological capabilities, and support for Hypothesis 3 is not robust.

We further proposed that market growth has a moderating effect on the alliance proactiveness-performance relationship (Hypothesis 4). Model 3 shows this interaction to be statistically significant $(b=0.310, p=0.002)$. When we add further moderating effects to the model, the size of the coefficient and its level of significance is reduced but still significant $(b=0.219, p=0.025$ in Model $6, b=0.196, p=0.061$ in Model 7, and $b=0.195, p=0.056$ in Model 8). The effect is illustrated in Figure 3. This suggests that for an average firm, the effect is indeed positive as suggested in Hypothesis 4.

\section{*** Insert Figure 3 about here ***}

In Hypothesis 5, we proposed a three-way interaction between alliance proactiveness, technological capabilities and market growth in driving firm 
performance. Model 9 shows that the three-way interaction effect is statistically significant $(b=0.267, p=0.003)$. Figure 4 illustrates this interaction. Thus, Hypothesis 5 is supported; alliance proactiveness adds most value to firm performance if it is combined with technological capabilities and applied in a fast growing market.

\footnotetext{
*** Insert Figure 4 about here ***
}

\section{DISCUSSION}

\section{Contributions}

We have argued that alliance proactiveness enhances firm performance especially when combined with other capabilities of the firm, and when deployed in fast growing markets. Our empirical tests suggest that alliance proactiveness indeed interacts with both capabilities and market growth; probably most interesting is the finding that the combination of alliance proactiveness with technological capabilities and market growth has the highest impact on firm performance.

We contribute to the literature on alliances in business in several ways. First, building on dynamic and relational capabilities theorizing, we sharpen the theoretical understanding of alliance proactiveness, a key facet of alliance management capability. Extending on recent studies on alliance management capability (e.g., Leischnig \& Geigenmüller, 2018; Sarkar et al., 2009), we argue that proactiveness in forming alliances helps firms to respond more effectively to emergent market opportunities, and therefore is critical for organizing alliances to generate longer term benefits. We provide new empirical support for the positive association of alliance proactiveness and firm performance from an emerging economy, and thus demonstrate the relevance of the concept in emerging economy contexts.

Second, we explore internal contingencies of alliance proactiveness. This study is among the first to explore complementarities of different types of capabilities with alliance proactiveness. Going beyond Leischnig et al. (2014) who examine the direct effect of alliance management capability on technology transfer, our empirical 
findings show evidence of a positive interaction between alliance proactiveness and technological capabilities in their impact on firm performance, while the association with leader strategic competences receives partial support. The complementarity of alliance proactiveness and technological capabilities underpins complementarity of higher level constructs of capabilities discussed in recent industrial marketing research (Forkmann, Henneberg, \& Mitrega, 2018; O’Cass, Ngo, \& Siahtiri, 2015; Zhang \& Wu, 2017). Specifically, dynamic capabilities such as alliance proactiveness are valuable if they can be combined with operational capabilities so as to balance the exploitation and exploration of resources in a changing environment (e.g., Dixon, Meyer, \& Day, 2010; Song et al., 2005; Wilden \& Gudergan, 2015).

Our results provide only limited support for the moderating effect of leader strategic competences. Specifically, leader strategic competences do not seem to add value once we account for technological capabilities. Consistent with prior research, this suggests a dominance of technological capabilities over leadership capabilities (Leiblein \& Miller, 2003). Again, without a foundation in technology (or quality products and services), even competent management will find it difficult to use alliances to their advantage.

Third, we answer to the call of Wang and Rajagopalan (2014) to better explain how specific environmental attributes affect alliance management capability. Different contexts create different challenges or opportunities that influence firm performance outcomes. In particular, the literature on business in emerging economies has repeatedly called for a better understanding of contextual boundary conditions for theorizing on strategy (Xu \& Meyer, 2013; Meyer \& Peng, 2016), and on industrial marketing in particular (Murphy \& Li, 2015; Zhang \& Wu, 2015). We explore the external contingencies of market growth because it opens up new business opportunities and encourages more alliance activities. Our results indicate support for the moderating role of market growth both in a 2-way interaction with alliance proactiveness and in a 3-way interaction with alliance proactiveness and technological capabilities. Thus, performance of alliance proactive firms is higher in environments 
where new business opportunities are abundant. Moreover, our results suggest that firms with strong technological capabilities that are proactive in alliance formation benefit most from a booming market environment.

\section{Managerial implications}

Insights from our study are particularly relevant for firms in fast growing emerging markets. Many MNE subsidiaries find the local environment in emerging economies challenging to navigate. They may believe that technological advantages ought to provide them with competitive advantages, as mainstream international business theories suggest (Dunning 1997; Narula \& Verbeke, 2015). However, our results suggest that technology-based advantages may not be sufficient: they need to be combined with alliance management capability to be exploited successfully in an emerging economy.

The development of capabilities such as alliance proactiveness takes time and may be costly (Schilke, 2014). Under constraints on firm resources and managerial attention (Ardichvili et al., 2003), firms face trade-offs and need to prioritize resource development. Our findings offer insights on how to prioritize: technologically strong firms appear to benefit more from alliance proactiveness; in other words, proactive alliance management contributes more to the performance of technologically strong firms than to technologically weak firms. Hence, the development of multiple types of capabilities, though challenging, is crucial to firm success. On the other hand, our findings suggest that it may be more important to develop technological capabilities than leader strategic competences to support alliance activities.

Moreover, environmental conditions play a key role in influencing the value created by proactive alliances. Specifically, abundant opportunities in the market reinforce the positive impact of alliance proactiveness and technological capabilities on performance. In our research context of China, where firms' technological levels are relatively low and firms may be constrained by institutional adversity, it is more important for firms to go beyond acquiring technological knowledge and more 
aggressively seize alliance opportunities to outcompete competitors. Emerging economies present high growth potential, which provides domestic and foreign firms alike abundant opportunities to gain superior performance.

\section{Limitations and future research}

One limitation of our study is that we focus on only one dimension of alliance management capability. In particular, alliance proactiveness is more relevant to the alliance formation phase but arguably less for post-formation processes such as interorganizational learning and managing cooperative relations. However, alliance performance depends on how alliances are managed throughout their lifetime, and in particular how firms manage their learning processes in and from the alliance (e.g., Sluyts et al., 2011). Our conceptualization and measurement of alliance proactiveness focuses on the formation and design of alliances. Thus, future research may examine all four dimensions of alliance management capability of both partners, and study various stages of alliances (i.e., alliance formation and post-formation management) to reveal the whole process of alliance management.

Further limitations arise from the relatively small set of firms in our dataset. The need for two respondents from each firm (to minimize CMV) reduced the number of observations and hence the degrees of freedom in the regression analysis. In consequence, we have not been able to include some control variables that would have been desirable, such as more fine-grained industry controls, or controls for firm characteristics such as alliance experience.

More broadly, this research focuses on alliances with non-competitors, while ignoring collaboration with competitors. Building on recent work on coopetition (e.g., Bengtsson, Raza-Ullah, \& Vanyushyn, 2016; Bouncken, Clauss, \& Fredrich, 2016; Ritala, Golnam, \& Wegmann, 2014), future research may examine the alliance management capability needed to create and capture value in coopetive relationships. There may be specific capabilities for managing a collaborative relationship while 
competing with the partner in other areas, and thus be particularly concerned about unintended 'knowledge leakage' to the partner (Jiang et al., 2013).

Finally, industrial marketing research ought to pay greater attention to emerging economies. Many of the world's supply chains extend into emerging economies, and engage in B-to-B interfaces with local suppliers or customers (Prashantham \& Yip, 2019; Wiersema, 2013). External contingencies are clearly important in these contexts for firm performance. Industrial marketing researchers have recently began to explore challenges of managing B-to-B relationships in countries such as Brazil (Vieira, Monteiro, \& Veiga, 2011), China (Cui et al., 2018; Jiang et al., 2013; Murphy \& Li, 2015) and Thailand (Rungsithong et al., 2017). Yet, we lack theoretical and empirical knowledge on how companies can best handle different types of environmental configurations in emerging economies.

\section{CONCLUSIONS}

The concept of alliance proactiveness holds considerable potential to explain why some firms are more successful than others in using strategic alliances to their own advantage. Our study shows not only the direct effect of alliance proactiveness on firm performance, but also its internal and external contingencies. Alliance proactiveness has the largest impact on firms that can draw upon their own technological capabilities while facing a fast growing market environment. Under such conditions, the ability to establish relationships quickly and effectively with partners holding complementary capabilities can yield particularly large returns to early movers. 


\section{References:}

Afuah, A. (2000). How much do your co-opetitors' capabilities matter in the face of technological change? Strategic Management Journal, 21(3), 387-404.

Alvarez, S. A., \& Busenitz, L. (2001). The entrepreneurship of resource-based theory. Journal of Management, 27, 755-775.

Anand, B. N., \& Khanna, T. (2000). Do firms learn to create value? The case of alliances. Strategic Management Journal, 21(3), 295-315.

Anderson, J. C., \& Gerbing, D. W. (1988). Structural equation modeling in practice: A review and recommended two step approach. Psychological Bulletin, 103(3), 411-423.

Andrevski, G., Brass, D. J., \& Ferrier, W. J. (2016). Alliance portfolio configurations and competitive action frequency. Journal of Management, 42(4), 811-837.

Ardichvili, A., Cardozo, R., \& Ray, S. (2003). A theory of entrepreneurial opportunity identification and development. Journal of Business Venturing, 18(1), 105-123.

Baum, J., Calabrese, T., \& Silverman, B. (2000). Don't go it alone: Alliance network composition and startups' performance in Canadian Biotechnology. Strategic Management Journal, 21, 267-294.

Bengtsson, M., Raza-Ullah, T., \& Vanyushyn, V. (2016). The coopetition paradox and tension: The moderating role of coopetition capability. Industrial Marketing Management, 53, 19-30.

Bouncken, R. B., Clauss, T., \& Fredrich, V. (2016). Product innovation through coopetition in alliances: Singular or plural governance. Industrial Marketing Management, 53, 77-90.

Calantone, R. J., Cavusgil, S. T., \& Zhao, Y. (2002). Learning orientation, firm innovation capability, and firm performance. Industrial Marketing Management, 31, 515-524.

Covin, J. G., \& Slevin D. P. (1989). Strategic management of small firms in hostile and benign environments. Strategic Management Journal, 10(1), 75-87.

Cui, L., Fan, D., Guo, F., \& Fan, Yi. (2018). Explicating the relationship of entrepreneurial orientation and firm performance: Underlying mechanisms in the context of an emerging market. Industrial Marketing Management, 71, 27-40.

D’Aveni, R. A., Dagnino, G. B., \& Smith, K. G. (2010). The age of temporary advantage. Strategic Management Journal, 31, 1371-1385.

Dixon, S. E., Meyer, K. E., \& Day, M. 2010. Stages of organizational transformation in transition economies: A dynamic capabilities approach. Journal of Management Studies, 47(3), 416-436.

Doz, Y. L., \& Hamel, G. (1998). Alliance advantage: The art of creating value through partnering. Boston, MA: Harvard Business School Press.

Dunning, J. H. 1997. Alliance Capitalism and Global Business. London and New York: Routledge.

Dyer, J. H., \& Kale, P. (2007). Relational capabilities: Drivers and implications. In C.

E. Helfat, S. Finkelstein, W. Mitchell, M. A. Peteraf, H. Singh, D. J. Teece, \& S.

G. Winter (Eds.), Dynamic capabilities: Understanding strategic change in organizations (pp. 65-79). Malden, MA: Blackwell Publishing. 
Dyer, J. H., \& Singh, H. (1998). The relational view: Cooperative strategy and sources of interorganizational competitive advantage. Academy of Management Review, 23(4), 660-679.

Eisenhardt, K. M., \& Martin, J. A. (2000). Dynamic capabilities: What are they? Strategic Management Journal, 21(10/11), 1105-1121.

Ferrier, W., Smith, K., \& Grimm, C. (1999). The role of competition in market share erosion and dethronement: A study of industry leaders and challengers. Academy of Management Journal, 42, 372-388.

Finkelstein, S., \& Hambrick, D. (1996). Strategic leadership: Top executives and their effects on organizations. Minneapolis, MN: West.

Forkmann, S., Henneberg, S. C., \& Mitrega, M. (2018). Capabilities in business relationships and networks: Research recommendations and directions. Industrial Marketing Management, advance online.

Frynas, J. G., Mellahi, K., \& Pigman, G. A. (2006). First mover advantages in international business and firm-specific political resources. Strategic Management Journal, 27, 321-345.

Gomes-Casseres, B. (1996). The alliance revolution: The new shape of business rivalry. Cambridge, MA: Harvard Business Press.

Gulati, R. (1995). Social structure and alliance formation patterns: A longitudinal analysis. Administrative Science Quarterly, 40(4), 619-652.

Gulati, R., Lavie, D., \& Singh, H. (2009). The nature of partnering experience and the gains from alliances. Strategic Management Journal, 30, 1213-1233.

Haeussler, C., Patzelt, H., \& Zahra, S. A. (2012). Strategic alliances and product development in high technology new firms: The moderating effect of technological capabilities, Journal of Business Venturing, 27, 217-233.

Hagedoorn, J., \& Schakenraad, J. (1994). The effect of strategic technology alliances on company performance. Strategic Management Journal, 15, 291-309.

Hamilton, B. H., \& Nickerson, J. A. (2003). Correcting for endogeneity in strategic management research. Strategic Organization, 1(1), 51-78.

He, X., \& Li, X. (2005). Entrepreneurial competence and enterprise growth: An empirical study in China. Economic Research Journal (in Chinese), 10, 101-111.

Heckman, J. (1979). Sample selection bias as a specification error. Econometrica, 47(1), 153-162.

Heimeriks, K. H., \& Duysters, G. (2007). Alliance capability as a mediator between experience and alliance performance: An empirical investigation into the alliance capability development process. Journal of Management Studies, 44(1), 25-49.

Hitt, M. A., Ahlstrom, D., Dacin, T. M., Levitas, E., \& Svobodina, A. (2004). The institutional effects on strategic alliance partner selection in transition economies: China vs. Russia. Organization Science, 15(2), 173-185.

Holcomb, T. R., Holmes, R. M., \& Connelly, B. L. (2009). Making the most of what you have: Managerial ability as a source of resource value creation. Strategic Management Journal, 30, 457-485.

Hughes, M., \& Morgan, R. E. (2007). Deconstructing the relationship between entrepreneurial orientation and business performance at the embryonic stage of 
firm growth. Industrial Marketing Management, 36(5), 651-661.

Jiang, X., Li, M., Gao, S. X., Bao, Y. C., \& Jiang, F. F. (2013). Managing knowledge leakage in strategic alliances: The effects of trust and formal contracts. Industrial Marketing Management, 42(6), 983-991.

Kale, P., Dyer, J. H., \& Singh, H. (2002). Alliance capability, stock market response, and long-term alliance success: The role of the alliance function. Strategic Management Journal, 23, 747-767.

Kale, P., \& Singh, H. (2007). Building firm capabilities through learning: The role of the alliance learning process in alliance capability and firm-level alliance success. Strategic Management Journal, 28(10), 981-1000.

Katila, R., Rosenberger, J. D., \& Eisenhardt, K. M. (2008). Swimming with sharks: Technology ventures, defense mechanism and corporate relationships. Administrative Science Quarterly, 53(2), 295-332.

KPMG. (2012). The future for MNCs in China. www.kpmg.com/cn.

Kreiser, P. M., Marino, L. D., Kuratko, D. F., \& Weaver, K. M. (2013). Disaggregating entrepreneurial orientation: The non-linear impact of innovativeness, proactiveness and risk taking on SME performance. Small Business Economics, 40, 273-291.

Lado, A. A., Boyd, N. G., \& Hanlon, S. C. (1997). Competition, cooperation, and the search for economic rent: A syncretic model. Academy of Management Review, $22,110-141$.

Lane, P. J., \& Lubatkin, M. H. (1998). Relative absorptive capacity and interorganizational learning. Strategic Management Journal, 19(5), 461-477.

Lavie, D. (2006). The competitive advantage of interconnected firms: An extension of the resource-based view. Academy of Management Review, 31(3), 638-658.

Lee, C., Lee, K., \& Pennings, J. M. (2001). Internal capabilities, external networks, and performance: A study on technology-based ventures. Strategic Management Journal, 22, 615-640.

Leiblein, M. J., \& Miller, D. J. (2003). An empirical examination of transaction- and firm-level influences on the vertical boundaries of the firm. Strategic Management Journal, 24, 839-859.

Leischnig, A., \& Geigenmüller, A. (2018). When does alliance proactiveness matter to market performance? A comparative case analysis. Industrial Marketing Management, advance online.

Leischnig, A., Geigenmüller, A., \& Lohmann, S. (2014). On the role of alliance management capability, organizational compatibility, and interaction quality in interorganizational technology transfer. Journal of Business Research, 67, 10491057.

Li, H., \& Miller, T. (2006). New ventures in emerging markets: Comprehensive review and future directions. In $\mathrm{H}$. Li (Ed.), Growth of new technology ventures in China's emerging market (pp. 11-24). Northampton, MA: Edward Elgar Publishing Ltd.

Lieberman, M. B., \& Montgomery, D. B. (1998). First-mover (dis)advantages: Retrospective and link with the resource-based view. Strategic Management Journal, 19(12), 1111-1125. 
Lin, Z., Yang, H., \& Arya, B. (2009). Alliance partners to firm performance: Resource complementarity and status association. Strategic Management Journal, 30, 921-940.

Lumpkin, G. T., \& Dess, G. G. (1996). Clarifying the entrepreneurial orientation construct and linking it to performance. Academy of Management Review, 21(1), $135-172$.

Luo, Y. (2003). Industrial dynamics and managerial networking in an emerging market: The case of China. Strategic Management Journal, 24(13), 1315-1327.

Medlin, C. J., \& Ellegaard, C. (2015). Conceptualizing competition and rivalry in a networking business market. Industrial Marketing Management, 51, 131-140.

Meyer, K. E., \& Peng, M W. (2016). Theoretical foundations of emerging economy research. Journal of International Business Studies, 47(1), 3-22.

Miller, D. (2011). Miller (1983) revisited: A reflection on EO research and some suggestions for the future. Entrepreneurship Theory and Practice, 35(5), 873894.

Mitrega, M., Forkmann, S., Ramos, C., \& Henneberg, S. C. (2012). Networking capability in business relationships - Concept and scale development. Industrial Marketing Management, 41(5), 739-751.

Mitrega, M., Henneberg, S. C., \& Forkmann, S. (2018). Capabilities in business relationships and networks: An introduction to the special issue. Industrial Marketing Management, advance online.

Montgomery, C. A. (2008). Putting leadership back into strategy. Harvard Business Review, 86, 54-60.

Morgan, N. A., Vorhies, D. W., \& Mason, C. H. (2009). Market orientation, marketing capabilities, and firm performance. Strategic Management Journal, 30(8): 909920.

Murphy, W. H., \& Li, N. (2015). Government, company, and dyadic factors affecting key account management performance in China: Propositions to provoke research. Industrial Marketing Management, 51, 115-121.

Narula, R., \& Verbeke, A. 2015. Making internalization theory good for practice: The essence of Alan Rugman's contributions to international business. Journal of World Business, 50(4), 612-622.

O’Cass, A., Ngo, L.V., \& Siahtiri, V. (2015). Marketing resource-capability complementarity and firm performance in B2B firms. Journal of Business \& Industrial Marketing, 30(2), 194-207.

Ozcan, P., \& Eisenhardt, K. M. (2009). Origin of alliance portfolios: Entrepreneurs, network strategies, and firm performance. Academy of Management Journal, 52(2), 246-279.

Ozdemir, S., Kandemir, D., \& Eng, T.-Y. (2017). The role of horizontal and vertical new product alliances in responsive and proactive market orientations and performance of industrial manufacturing firms. Industrial Marketing Management, 64, 25-35.

Pagano, A. (2009). The role of relational capabilities in the organization of international sourcing activities: literature review. Industrial Marketing 
Management, 38(8), 903-913.

Park, S. H., Chen, R., \& Gallagher, S. (2002). Firm resources as moderators of the relationship between market growth and strategic alliances in semiconductor start-ups. Academy of Management Journal, 45(3), 527-545.

Podsakoff, P. M., MacKenzie, S. B., Lee, J., \& Podsakoff, N. P. (2003). Common method biases in behavioral research: A critical review of the literature and recommended remedies. Journal of Applied Psychology, 88, 879-903.

Powell, W. W. (1998). Learning from collaboration: Knowledge and networks in the biotechnology and pharmaceutical industries. California Management Review, 40(3), 228-240.

Powell, W. W., Koput, K. W., \& Smith-Doerr, L. (1996). Interorganizational collaboration and the locus of innovation: Networks of learning in biotechnology. Administrative Science Quarterly, 41, 116-145.

Prashantham, S., \& Yip, G. (2019). Local firms within global value chains: From local assembler to value partner. In R. Grosse, \& K. E. Meyer (Eds.), Oxford handbook of management in emerging markets, Oxford University Press, (pp. 591-608). .

Reuer, J. J., Zollo, M., \& Singh, H. (2002). Interorganizational routines and performance in strategic alliances. Organization Science, 13(6), 701-713.

Ritala, P., Golnam, A., \& Wegmann, A. (2014). Coopetition-based business models: The case of Amazon.com. Industrial Marketing Management, 43, 236-249.

Rothaermel, F. T. (2001). Incumbent's advantage through exploiting complementary assets via interfirm cooperation. Strategic Management Journal, 22, 687-699.

Rothaermel, F. T., \& Boeker, W. (2008). Old technology meets new technology: Complementarities, similarities, and alliance formation. Strategic Management Journal, 29(1), 47-77.

Rothaermel, F. T., \& Deeds, D. L. (2004). Exploration and exploitation alliances in biotechnology: A system of new product development. Strategic Management Journal, 25, 201-221.

Rungsithong, R., Meyer, K. E., \& Roath, A. S. (2017). Relational capabilities in Thai buyer-supplier relationships. Journal of Business and Industrial Marketing, 32(8), 1228-1244.

Santos, F. M., \& Eisenhardt, K. M. (2009). Constructing markets and shaping boundaries: Entrepreneurial power in nascent fields. Academy of Management Journal, 52(4), 643-671.

Sarkar, M., Aulakh, P. S., \& Madhok, A. (2009). Process capabilities and value generation in alliance portfolios. Organizational Science, 20, 583-600.

Sarkar, M., Echambadi, R., \& Harrison, J. S. (2001). Alliance entrepreneurship and firm market performance. Strategic Management Journal, 22, 701-711.

Schilke, O. (2014). Second-order dynamic capabilities: How do they matter? Academy of Management Perspectives, 28(4), 368-380.

Schilke, O., \& Goerzen, A. (2010). Alliance management capability: An investigation of the construct and its measurement. Journal of Management, 36(5), 1192-1219.

Schreiner, M., Kale, P., \& Corsten, D. (2009). What really is alliance management 
capability and how does it impact on alliance outcome and success? Strategic Management Journal, 30, 1395-1419.

Sharma, S., \& Vredenburg, H. (1998). Proactive corporate environmental strategy and the development of competitively valuable organizational capabilities. Strategic Management Journal, 19(8), 729-753.

Sheth, J. N. (2011). Impact of emerging markets on marketing: Rethinking existing perspectives and practices. Journal of Marketing, 75(4), 166-82.

Sluyts, K., Matthyssens, P., Martens, R., \& Streukens, S. (2011). Building capabilities to manage strategic alliances. Industrial Marketing Management, 40, 875-886.

Song, M., Droge, C., Hanvanich, S., \& Calantone, R. (2005). Marketing and technology resource complementarity: an analysis of their interaction effect in two environmental contexts. Strategic Management Journal, 26(3), 259-276.

Stuart, T. E. (2000). Interorganizational alliances and the performance of firms: A study of growth and innovation rates in a high-technology industry. Strategic Management Journal, 21(8), 791-811.

Teece, D. J. (1986). Profiting from technological innovation: Implications for integration, collaboration, licensing and public policy. Research Policy, 15(6), 285-305.

Teece, D. J., Pisano, G., \& Shuen, A. (1997). Dynamic capabilities and strategic management. Strategic Management Journal, 18, 509-533.

Venkatraman, N. (1989). Strategic orientation of business enterprises: The construct, dimensionality, and measurement. Management Science, 35, 942-962.

Vieira, V. A., Monteiro, P. R. R., \& Veiga, R. T. (2011). Relationship marketing in supply chain: An empirical analysis in the Brazilian service sector. Journal of Business \& Industrial Marketing, 26(7), 524-531.

Wang, Y., \& Rajagopalan, N. (2014). Alliance capabilities: Review and research agenda. Journal of Management, 41(1), 236-260.

Wiersema, F. (2013). The B2B Agenda: The current state of B2B marketing and a look ahead. Industrial Marketing Management, 42, 470-488.

Wilden, R., \& Gudergan, S. P. (2015). The impact of dynamic capabilities on operational marketing and technological capabilities: Investigating the role of environmental turbulence. Journal of the Academy of Marketing Science, 43(2), 181-199.

Xu, D. \& Meyer, K. E. (2013). Linking theory and context: Strategy research in emerging economies, Journal of Management Studies, 50(7), 1322-1346.

Yang, W., \& Meyer, K. E. (2015). Competitive dynamics in an emerging economy: Competitive pressures, resources, and the speed of action. Journal of Business Research, 68, 1176-1185.

Zhang, J. F., \& Wu, W. P. (2017). Leveraging internal resources and external business networks for new product success: A dynamic capabilities perspective. Industrial Marketing Management, 61, 170-181.

Zhou, K. Z., \& Wu, F. (2010). Technological capability, strategic flexibility, and product innovation. Strategic Management Journal, 31, 547-561. 


\section{Appendix A. Measures and questionnaire items}

\begin{tabular}{|c|c|}
\hline Variables and items & SFL \\
\hline $\begin{array}{l}\text { Alliance proactiveness }[\mathbf{M}] \text { : Has your business unit initiated an alliance or } \\
\text { cooperative agreement in the last } 12 \text { months, and how speedily/how often has } \\
\text { it been doing that, relative to the major competitors? }(1=\text { far slower/fewer } \\
\text { than competitors, } 7=\text { far faster/more than competitors) } C R=0.897\end{array}$ & \\
\hline 1. Speed of initiating alliance or cooperative agreement & 0.953 \\
\hline 2. Frequency of initiating alliance or cooperative agreement & 0.953 \\
\hline $\begin{array}{l}\text { Technological capabilities [T]: Please rate your company, relative to your major } \\
\text { competitors in terms of its technological capabilities in the following areas. Circle } \\
\text { a number for each capability }(1=\text { much worse than competitors, } 7=\text { much better } \\
\text { than competitors). } C R=0.884\end{array}$ & \\
\hline 1. Acquiring important technology information & 0.805 \\
\hline 2. Identifying new technology opportunities & 0.861 \\
\hline 3. Responding to technology changes & 0.832 \\
\hline 4. Mastering state-of-the-art technologies & 0.827 \\
\hline 5. Practising continuous innovation & 0.814 \\
\hline $\begin{array}{l}\text { Leader strategic competences [T]: Please rate your company, relative to your } \\
\text { major competitors in terms of how your senior management team does the } \\
\text { following ( } 1=\text { much worse than competitors, } 7=\text { much better than competitors). } \\
\mathrm{CR}=0.906\end{array}$ & \\
\hline 1. Accurately position the company in the market & 0.831 \\
\hline 2. Adjust the strategic goals and operations of the company in timely fashion & 0.889 \\
\hline $\begin{array}{l}\text { 3. Re-organize resource immediately in order to adjust to changes in the } \\
\text { environment }\end{array}$ & 0.882 \\
\hline 4. Formulate ambitious strategic goals and plans & 0.770 \\
\hline 5. Increase or decrease business activities rapidly in order to realize strategic goals & 0.785 \\
\hline $\begin{array}{l}\text { 6. Come up with new and creative ideas and proposals in order to catch up } \\
\text { opportunities }\end{array}$ & 0.805 \\
\hline \multicolumn{2}{|l|}{$\begin{array}{l}\text { Market growth [T]: To what extent do you agree with the following statements } \\
\text { regarding market growth of your main business activity in China? }(1=\text { strongly } \\
\text { disagree, } 7=\text { strongly agree) } \mathrm{CR}=0.850\end{array}$} \\
\hline 1. The growth rate of this industry in the past three years was high. & 0.842 \\
\hline
\end{tabular}




\begin{tabular}{|c|c|}
\hline 2. Market demand in this industry is growing rapidly. & 0.917 \\
\hline $\begin{array}{l}\text { 3. The many potential customers in this industry provide major opportunities for } \\
\text { my company. }\end{array}$ & 0.873 \\
\hline $\begin{array}{l}\text { Performance }[\mathbf{M}] \text { : Please evaluate your major line of business in the last } 12 \\
\text { months, relative to your major competitors }(1=\text { much worse than competitors, } 7= \\
\text { much better than competitors }) \mathrm{CR}=0.828\end{array}$ & \\
\hline 1. Market share growth & 0.841 \\
\hline 2. Acquiring new customers & 0.819 \\
\hline 3. Increasing sales to current customers & 0.757 \\
\hline 4. Growth in sales revenue & 0.657 \\
\hline 5. Business unit profitability & 0.921 \\
\hline 6. Reaching financial goals & 0.934 \\
\hline
\end{tabular}

$\mathrm{CR}=$ composite reliability; $\mathrm{SFL}=$ standardized factor loading. $\mathrm{T}=$ top manager respondent; $\mathrm{M}=$ middle manager respondent 
Table 1. Basic descriptive statistics and correlations

\begin{tabular}{|c|c|c|c|c|c|c|c|c|c|c|c|c|}
\hline Variables & Mean & s.d. & 1 & 2 & 3 & 4 & 5 & 6 & 7 & 8 & 9 & 10 \\
\hline 1 Firm age & 17.29 & 17.05 & & & & & & & & & & \\
\hline 2 Firm size & 3.05 & 0.86 & $0.33 * * *$ & & & & & & & & & \\
\hline 3 Wholly foreign & 0.25 & 0.41 & -0.15 & 0.07 & & & & & & & & \\
\hline 4 Joint venture & 0.05 & 0.23 & -0.03 & -0.01 & -0.13 & & & & & & & \\
\hline 5 Industry: B-to-C & 0.45 & 0.50 & $0.24 *$ & $0.43^{* * *}$ & 0.06 & 0.08 & & & & & & \\
\hline 6 Industry: Manufacturing & 0.71 & 0.46 & $0.24^{*}$ & -0.01 & -0.07 & 0.15 & -0.20 & & & & & \\
\hline 7 Alliance proactiveness & 4.08 & 1.66 & $-0.28 * *$ & 0.02 & -0.09 & 0.08 & -0.05 & $-0.24 *$ & & & & \\
\hline 8 Market growth & 5.23 & 1.32 & -0.06 & 0.01 & 0.02 & -0.07 & 0.18 & $-0.29 * *$ & -0.08 & & & \\
\hline 9 Technological capabilities & 5.21 & 0.96 & -0.12 & 0.17 & 0.01 & -0.01 & -0.01 & -0.05 & 0.09 & $0.35^{* * *}$ & & \\
\hline $\begin{array}{l}10 \text { Leader strategic } \\
\text { competences }\end{array}$ & 5.25 & 0.95 & -0.09 & $0.23 *$ & -0.01 & -0.10 & 0.04 & 0.00 & 0.19 & $0.27 * *$ & $0.49^{* * *}$ & \\
\hline 11 Performance & 4.61 & 0.99 & $-0.21 *$ & -0.13 & -0.05 & 0.09 & -0.16 & 0.10 & $0.33 * * *$ & 0.03 & 0.13 & 0.18 \\
\hline
\end{tabular}

$\mathrm{N}=93$ for the second-stage regression;

B-to-C = business-to-consumer;

Levels of significance: $* \mathrm{p}<0.05 ; * * \mathrm{p}<0.01$; *** $\mathrm{p}<0.001$. 
Table 2. Two-stage Heckman regression analysis

First stage selection equation

Second stage outcome equation (DV: firm performance)

(Alliance-or-not decision)

\begin{tabular}{|c|c|c|c|c|c|c|c|c|c|}
\hline & Model 1 & Model 2 & Model 3 & Model 4 & Model 5 & Model 6 & Model 7 & Model 8 & Model 9 \\
\hline Constant & $\begin{array}{l}1.443^{\dagger} \\
(0.737)\end{array}$ & $\begin{array}{l}2.896^{* *} \\
(0.902)\end{array}$ & $\begin{array}{c}3.243 * * * \\
(0.866)\end{array}$ & $\begin{array}{l}2.706^{* *} \\
(0.831)\end{array}$ & $\begin{array}{l}2.788^{* *} \\
(0.841)\end{array}$ & $\begin{array}{c}2.979 * * * \\
(0.817)\end{array}$ & $\begin{array}{c}3.030^{* * *} \\
(0.836)\end{array}$ & $\begin{array}{c}2.953 * * * \\
(0.815)\end{array}$ & $\begin{array}{c}3.134 * * * \\
(0.798)\end{array}$ \\
\hline \multicolumn{10}{|l|}{ Control variables } \\
\hline Firm age & $\begin{array}{c}0.003 \\
(0.011)\end{array}$ & $\begin{array}{l}-0.006 \\
(0.006)\end{array}$ & $\begin{array}{l}-0.007 \\
(0.006)\end{array}$ & $\begin{array}{c}-0.011^{\dagger} \\
(0.006)\end{array}$ & $\begin{array}{l}-0.008 \\
(0.006)\end{array}$ & $\begin{array}{c}-0.011^{\dagger} \\
(0.006)\end{array}$ & $\begin{array}{l}-0.008 \\
(0.006)\end{array}$ & $\begin{array}{c}-0.011^{\dagger} \\
(0.006)\end{array}$ & $\begin{array}{c}-0.013 * \\
(0.006)\end{array}$ \\
\hline Firm size & $\begin{array}{c}0.049 \\
(0.166)\end{array}$ & $\begin{array}{c}-0.121 \\
(0.133)\end{array}$ & $\begin{array}{l}-0.141 \\
(0.127)\end{array}$ & $\begin{array}{l}-0.030 \\
(0.125)\end{array}$ & $\begin{array}{c}-0.072 \\
(0.125)\end{array}$ & $\begin{array}{l}-0.057 \\
(0.122)\end{array}$ & $\begin{array}{l}-0.094 \\
(0.123)\end{array}$ & $\begin{array}{l}-0.056 \\
(0.121)\end{array}$ & $\begin{array}{l}-0.047 \\
(0.116)\end{array}$ \\
\hline Wholly foreign & $\begin{array}{c}0.080 \\
(0.295)\end{array}$ & $\begin{array}{c}0.037 \\
(0.225)\end{array}$ & $\begin{array}{c}0.049 \\
(0.214)\end{array}$ & $\begin{array}{l}-0.036 \\
(0.208)\end{array}$ & $\begin{array}{c}0.103 \\
(0.210)\end{array}$ & $\begin{array}{l}-0.016 \\
(0.202)\end{array}$ & $\begin{array}{c}0.097 \\
(0.207)\end{array}$ & $\begin{array}{c}0.013 \\
(0.205)\end{array}$ & $\begin{array}{l}-0.026 \\
(0.194)\end{array}$ \\
\hline Joint venture & $\begin{array}{c}-0.662 \\
(0.448)\end{array}$ & $\begin{array}{c}0.190 \\
(0.508)\end{array}$ & $\begin{array}{c}0.421 \\
(0.490)\end{array}$ & $\begin{array}{c}0.082 \\
(0.469)\end{array}$ & $\begin{array}{c}0.317 \\
(0.475)\end{array}$ & $\begin{array}{c}0.261 \\
(0.463)\end{array}$ & $\begin{array}{c}0.437 \\
(0.471)\end{array}$ & $\begin{array}{c}0.296 \\
(0.463)\end{array}$ & $\begin{array}{c}0.366 \\
(0.444)\end{array}$ \\
\hline Industry: B-to-C & $\begin{array}{c}0.367 \\
(0.281)\end{array}$ & $\begin{array}{l}-0.108 \\
(0.242)\end{array}$ & $\begin{array}{c}0.032 \\
(0.235)\end{array}$ & $\begin{array}{c}0.008 \\
(0.225)\end{array}$ & $\begin{array}{l}-0.018 \\
(0.227)\end{array}$ & $\begin{array}{c}0.090 \\
(0.222)\end{array}$ & $\begin{array}{c}0.052 \\
(0.226)\end{array}$ & $\begin{array}{c}0.087 \\
(0.221)\end{array}$ & $\begin{array}{c}0.114 \\
(0.212)\end{array}$ \\
\hline Industry: Manufacturing & $\begin{array}{c}0.318 \\
(0.285)\end{array}$ & $\begin{array}{c}0.453^{\dagger} \\
(0.254)\end{array}$ & $\begin{array}{c}0.387 \\
(0.242)\end{array}$ & $\begin{array}{l}0.499 * \\
(0.234)\end{array}$ & $\begin{array}{l}0.514 * \\
(0.237)\end{array}$ & $\begin{array}{l}0.446^{\dagger} \\
(0.228)\end{array}$ & $\begin{array}{l}0.460^{\dagger} \\
(0.234)\end{array}$ & $\begin{array}{l}0.461 * \\
(0.228)\end{array}$ & $\begin{array}{l}0.553 * \\
(0.221)\end{array}$ \\
\hline \multicolumn{10}{|l|}{ Main effects } \\
\hline $\begin{array}{l}\text { Alliance proactiveness } \\
\text { (AP) }\end{array}$ & & $\begin{array}{l}0.199^{* *} \\
(0.063)\end{array}$ & $\begin{array}{c}0.188^{* *} \\
(0.060)\end{array}$ & $\begin{array}{r}0.199 * * \\
(0.057)\end{array}$ & $\begin{array}{c}0.206^{* * *} \\
(0.058)\end{array}$ & $\begin{array}{l}0.191^{* *} \\
(0.056)\end{array}$ & $\begin{array}{l}0.198^{* *} \\
(0.057)\end{array}$ & $\begin{array}{l}0.193^{* *} \\
(0.056)\end{array}$ & $\begin{array}{l}0.158^{* *} \\
(0.055)\end{array}$ \\
\hline Market growth & & $\begin{array}{c}0.062 \\
(0.083)\end{array}$ & $\begin{array}{l}-0.061 \\
(0.089)\end{array}$ & $\begin{array}{c}0.068 \\
(0.076)\end{array}$ & $\begin{array}{c}0.074 \\
(0.078)\end{array}$ & $\begin{array}{l}-0.020 \\
(0.084)\end{array}$ & $\begin{array}{l}-0.006 \\
(0.087)\end{array}$ & $\begin{array}{l}-0.008 \\
(0.085)\end{array}$ & $\begin{array}{l}-0.036 \\
(0.081)\end{array}$ \\
\hline Technological capabilities & & $\begin{array}{c}0.031 \\
(0.117)\end{array}$ & $\begin{array}{c}0.092 \\
(0.113)\end{array}$ & $\begin{array}{c}0.050 \\
(0.107)\end{array}$ & $\begin{array}{c}0.027 \\
(0.109)\end{array}$ & $\begin{array}{c}0.091 \\
(0.106)\end{array}$ & $\begin{array}{c}0.067 \\
(0.109)\end{array}$ & $\begin{array}{c}0.082 \\
(0.107)\end{array}$ & $\begin{array}{c}0.126 \\
(0.106)\end{array}$ \\
\hline
\end{tabular}




\begin{tabular}{|c|c|c|c|c|c|c|c|c|c|}
\hline $\begin{array}{r}\text { Leader strategic } \\
\text { competences }\end{array}$ & & $\begin{array}{c}0.111 \\
(0.121)\end{array}$ & $\begin{array}{c}0.136 \\
(0.115)\end{array}$ & $\begin{array}{c}0.061 \\
(0.112)\end{array}$ & $\begin{array}{c}0.063 \\
(0.113)\end{array}$ & $\begin{array}{c}0.085 \\
(0.109)\end{array}$ & $\begin{array}{c}0.089 \\
(0.112)\end{array}$ & $\begin{array}{c}0.078 \\
(0.109)\end{array}$ & $\begin{array}{c}0.031 \\
(0.108)\end{array}$ \\
\hline \multicolumn{10}{|l|}{ Moderating effects } \\
\hline $\mathrm{AP} *$ market growth $(\mathrm{H} 4)$ & & & $\begin{array}{l}0.310^{* *} \\
(0.100)\end{array}$ & & & $\begin{array}{l}0.219^{*} \\
(0.098)\end{array}$ & $\begin{array}{c}0.196^{\dagger} \\
(0.105)\end{array}$ & $\begin{array}{c}0.195^{\dagger} \\
(0.102)\end{array}$ & $\begin{array}{c}0.172^{\dagger} \\
(0.096)\end{array}$ \\
\hline $\begin{array}{l}\text { AP } * \text { technological } \\
\text { capabilities }(\mathrm{H} 2)\end{array}$ & & & & $\begin{array}{c}0.384 * * * \\
(0.093)\end{array}$ & & $\begin{array}{c}0.328 * * * \\
(0.093)\end{array}$ & & $\begin{array}{l}0.268^{*} \\
(0.122)\end{array}$ & $\begin{array}{c}0.372 * * * \\
(0.090)\end{array}$ \\
\hline $\begin{array}{l}\mathrm{AP} * \text { leader strategic } \\
\text { competences }(\mathrm{H} 3)\end{array}$ & & & & & $\begin{array}{c}0.345^{* * *} \\
(0.092)\end{array}$ & & $\begin{array}{l}0.273^{* *} \\
(0.098)\end{array}$ & $\begin{array}{c}0.097 \\
(0.125)\end{array}$ & \\
\hline $\begin{array}{l}\text { Market growth * } \\
\text { technological } \\
\text { capabilities }\end{array}$ & & & & & & & & & $\begin{array}{c}0.072 \\
(0.083)\end{array}$ \\
\hline $\begin{array}{l}\text { AP * market growth * } \\
\text { technological } \\
\text { capabilities }(\mathrm{H} 5)\end{array}$ & & & & & & & & & $\begin{array}{c}0.267^{* *} \\
(0.089)\end{array}$ \\
\hline Inverse Mills ratio $(\lambda)$ & & $\begin{array}{c}0.043 \\
(0.945)\end{array}$ & $\begin{array}{l}-0.052 \\
(0.930)\end{array}$ & $\begin{array}{c}0.126 \\
(0.825)\end{array}$ & $\begin{array}{c}0.032 \\
(0.956)\end{array}$ & $\begin{array}{c}0.047 \\
(0.932)\end{array}$ & $\begin{array}{l}-0.026 \\
(0.964)\end{array}$ & $\begin{array}{c}0.038 \\
(0.945)\end{array}$ & $\begin{array}{c}0.144 \\
(0.785)\end{array}$ \\
\hline Industry lifecycle & $\begin{array}{l}-0.574 * \\
(0.227)\end{array}$ & & & & & & & & \\
\hline Wald chi-square $\left(\chi^{2}\right)$ & & $23.71^{* *}$ & $35.68 * * *$ & $45.21 * * *$ & $41.40 * * *$ & $52.75 * * *$ & $46.46 * * *$ & $53.70 * * *$ & $69.10 * * *$ \\
\hline No. of firms & 131 & 93 & 93 & 93 & 93 & 93 & 93 & 93 & 93 \\
\hline
\end{tabular}

The entries in the table are unstandardized coefficients. Standard errors in parentheses.

† $<<0.10$; $\mathrm{p}<0.05$; ** $\mathrm{p}<0.01$; *** $\mathrm{p}<0.001$. 
Figure 1 Theoretical framework

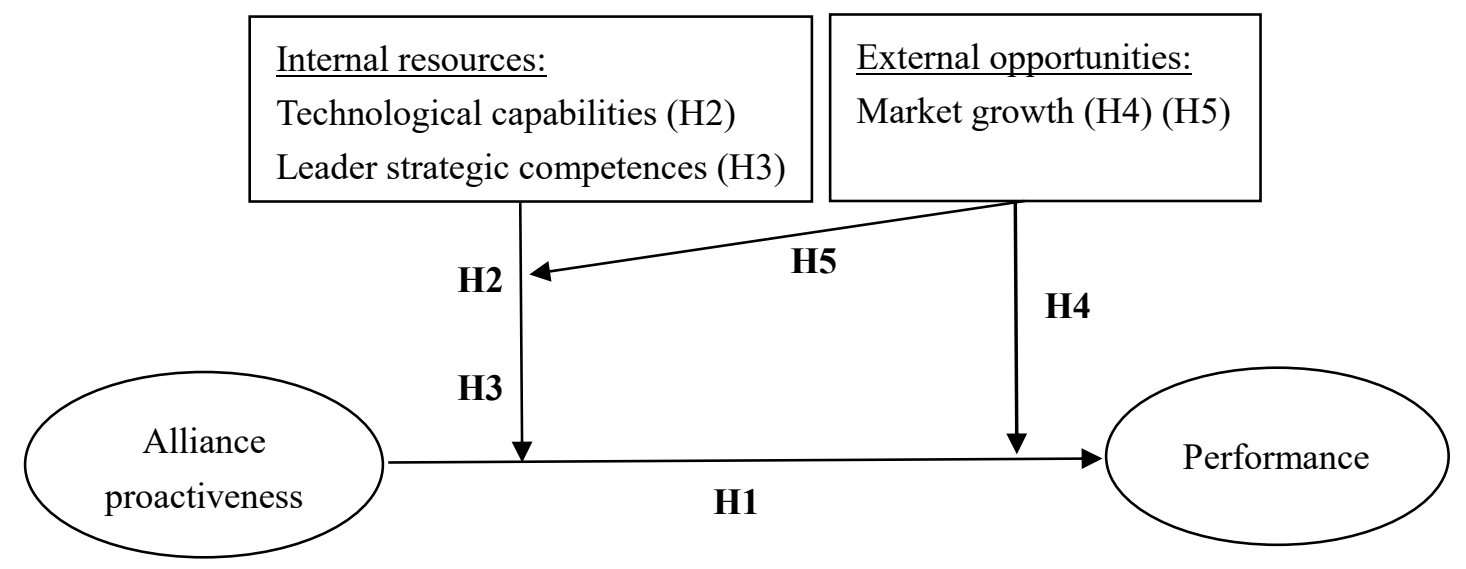

Figure 2 Moderating effect of technological capabilities on the relationship between alliance proactiveness and performance

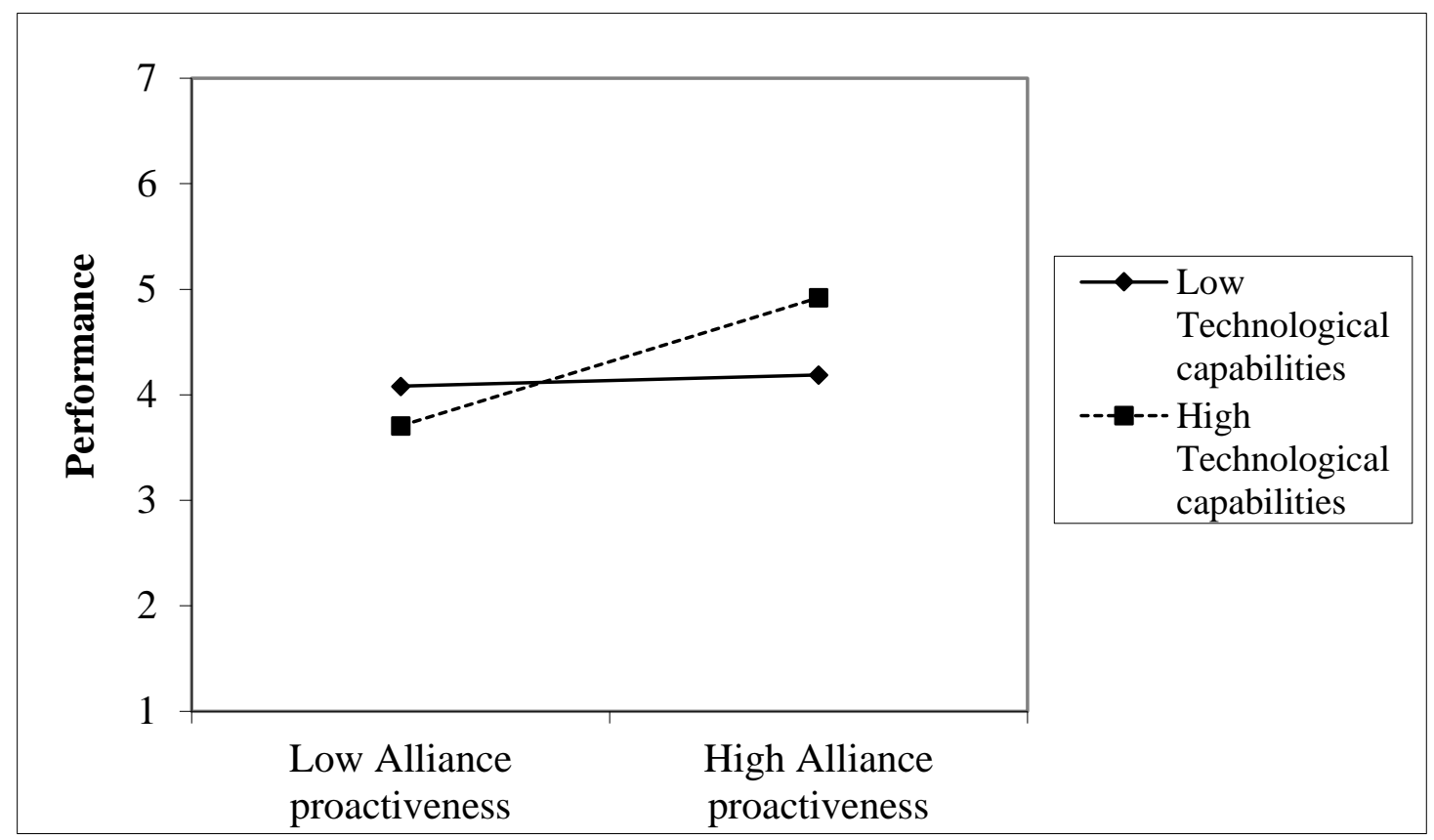

Note: This figure shows the marginal effect of alliance proactiveness on performance, based on model 8 in Table 2. Alliance proactiveness has a range of 1 to 7 , mean $=4.08$ and $\mathrm{SD}=$ 1.66. Hence, about $95 \%$ of observations fall in the range of mean $+/-2 \mathrm{SD}$, which is 0.76 to 7.40 . 
Figure 3 Moderating effect of market growth on the relationship between alliance proactiveness and performance

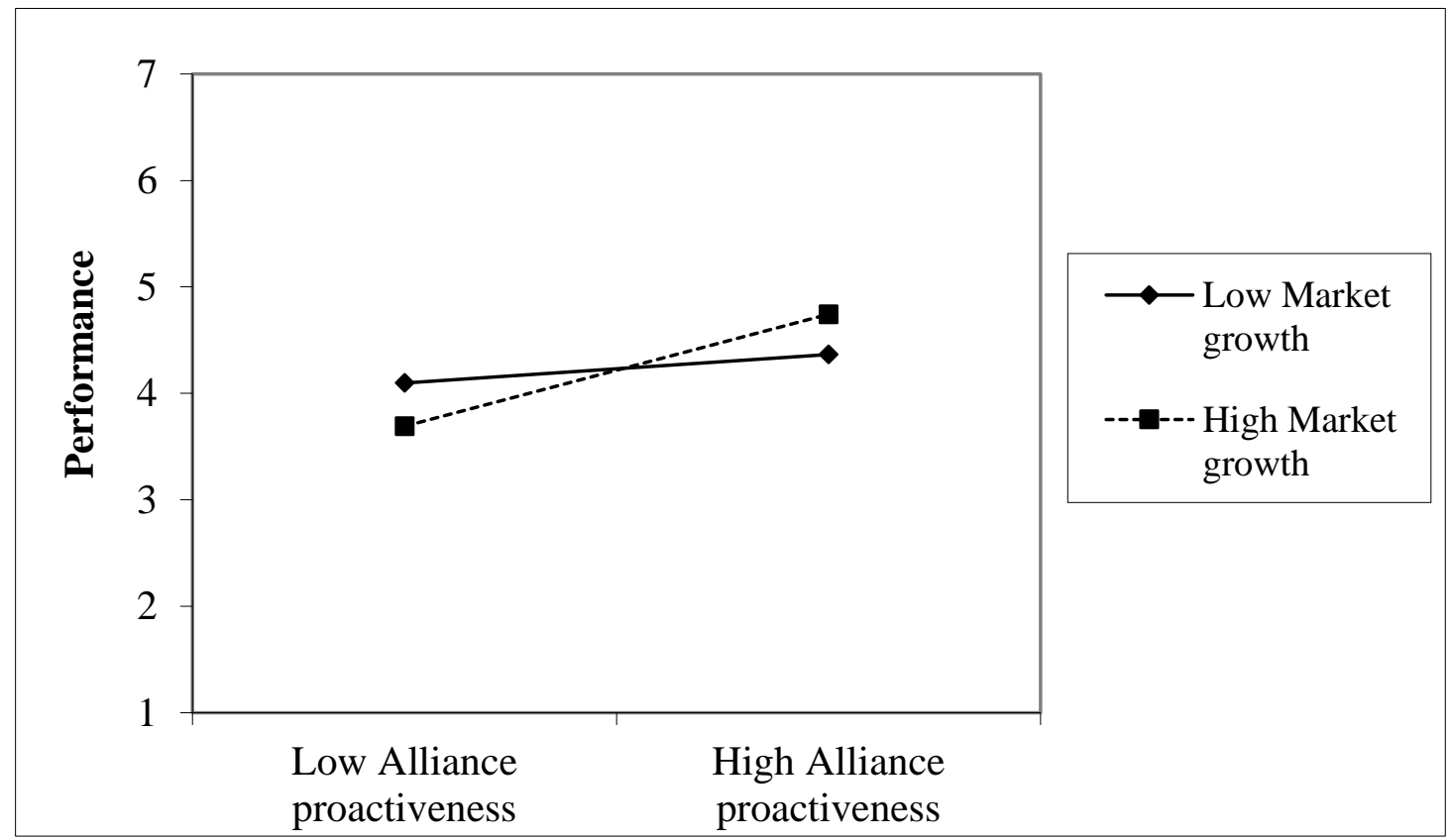

Note: This figure shows the marginal effect of alliance proactiveness on performance, based on model 8 in Table 2. Alliance proactiveness has a range of 1 to 7 , mean $=4.08$ and $\mathrm{SD}=$ 1.66. Hence, about $95 \%$ of observations fall in the range of mean $+/-2 \mathrm{SD}$, which is 0.76 to 7.40 . 
Figure 4 Moderating effect of technological capabilities and market growth on the relationship between alliance proactiveness and performance

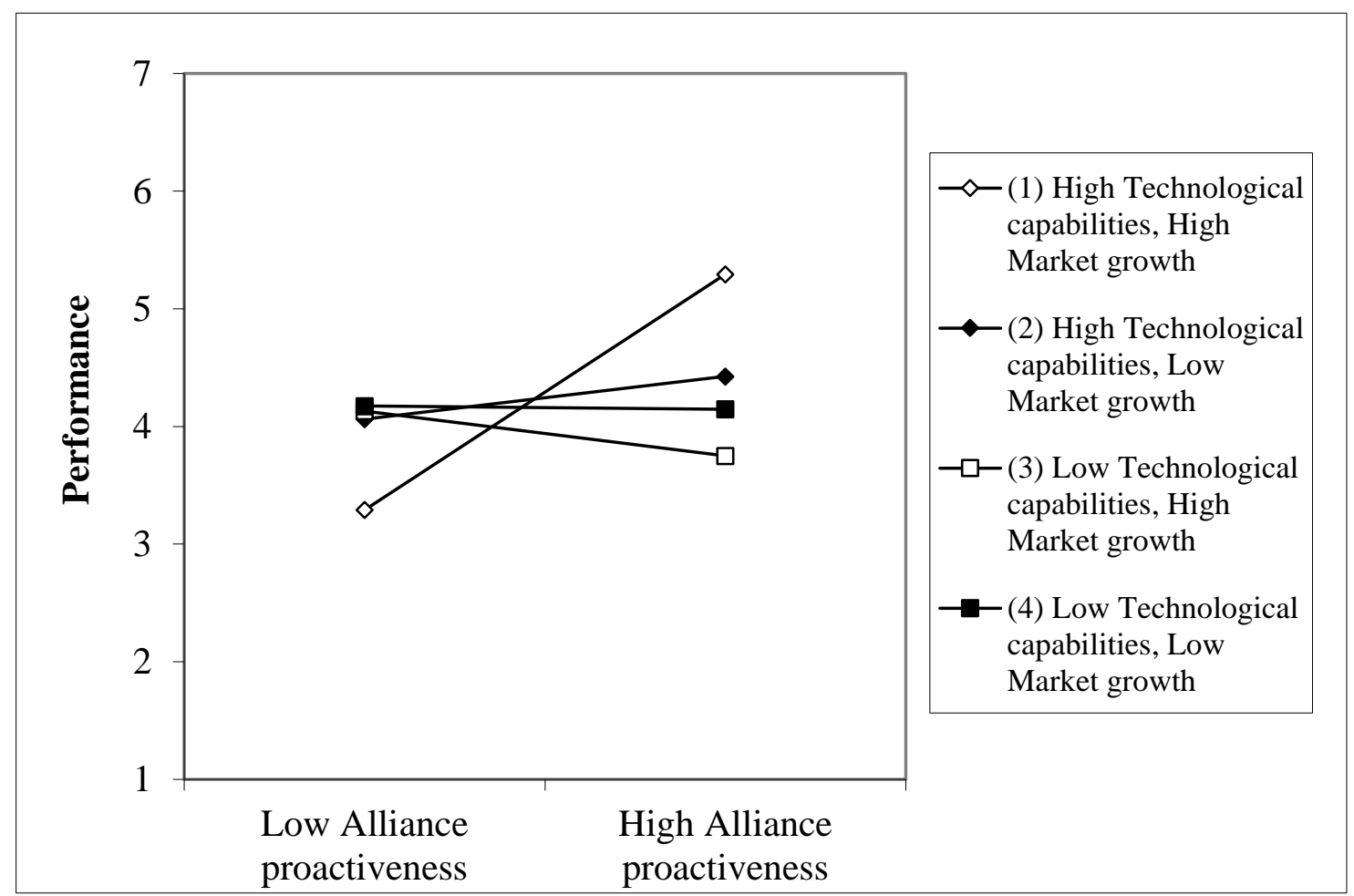

Note: This figure shows the marginal effect of alliance proactiveness on performance, based on model 9 in Table 2. Alliance proactiveness has a range of 1 to 7 , mean $=4.08$ and $\mathrm{SD}=$ 1.66. Hence, about $95 \%$ of observations fall in the range of mean $+/-2 \mathrm{SD}$, which is 0.76 to 7.40 . 